Yayın Geliş Tarihi: 03.07.2021

Yayına Kabul Tarihi: 28.12.2021

Online Yayın Tarihi: 31.12.2021

http://dx.doi.org/10.16953/ deusosbil.1055653
Dokuz Eylül Üniversitesi

Sosyal Bilimler Enstitüsü Dergisi

Cilt: 23, Özel Say1, Y1l: 2021, Sayfa: 231-248

ISSN: 1302-3284 E-ISSN: 1308-0911

Araştırma Makalesi

\title{
HAVA TAŞIMACILIĞI VE KENTLEŞME: TÜRKIYYE VE AVRUPA’NIN EN KALABALIK DÖRT ÜLKESINDEKİ BAĞLANTILILIK BULGULARI
}

\author{
Turan DÜNDAR* \\ Mehmet Aldonat BEYZATLAR ${ }^{* *}$
}

$\ddot{O} z$

Bu makalenin temel amacı, kentleşme ve ulaşım arasındaki dinamik etkileşimi gösterebilmektir. Bu çalışma, kentleşme ve hava taşımacılı̆̆l hareketliliği arasındaki bağlantılılı̆̆ın ampirik bir dĕgerlendirmesini sağlar. Ampirik kısım, 1970-2019 dönemine ait veri mevcudiyetine göre Türkiye ile Almanya, Birleșik Krallı, Fransa ve Italya için yıllık zaman serisi verilerini kullanır. İlgili değișkenler, kentleșme olarak kentsel nüfusun payın ve havayolu taşımacılığ ile yük ve yolcu hareketliliğini içerir. Kentleşme ve ulaşım verileri Dünya Bankası istatistik veri tabanından alınmıştır. Dinamik bağlantılılık yaklaşımı, hava taşımacılı̆̆ı hareketliliği ile kentleșme arasındaki bağlantının belirlenmesine farklı bir bakıs açısı getirebilecek, birinden hepsine, hepsinden bire, ăg, ikili ve toplam bă̆lantılılık endeksleri gibi çeşitli yayılma parametreleri sağlar. Elde ettiğimiz bulgular havayolu ulașımının yük ve yolcu bakımından kentleșme ile ilișkili olduğunu göstermektedir. Ulaşımın kentleşme ile olan dinamik yapısına ve yayılım sonuçlarına göre ulaşım alıcı iken kentleșme iletici konumundadır. Kentleşmeden ulaşıma doğru bir aktarım olması, özellikle ulaşım politikalarının kentsel alanlardaki etkililiği açısından önemlidir.

Anahtar Kelimeler: Kentleşme, Hava taşımacılı̆̆l, Yük ve yolcu hareketliliği bağlantılılık, Türkiye, Avrupa.

Bu makale için önerilen kaynak gösterimi (APA 6. Sürüm):

Dündar, T., Beyzatlar, M. A. (2022) Hava taşımacılığı ve kentleşme: Türkiye ve Avrupa'nın en kalabalık dört ülkesindeki bağlantılılık bulguları. Dokuz Eylül Üniversitesi Sosyal Bilimler Enstitüsü Dergisi, 23, Dokuz Eylül Üniversitesi Uluslararası Konferansı, Göç: Önümüzdeki Yirmi Yılın Projeksiyonu ve Ötesi” Özel Sayısı, 97-115.

* Yüksek Lisans Öğrencisi, Dokuz Eylül Üniversitesi, İşletme Fakültesi, İktisat Bölümü, ORCID: 0000-0002-8224-4951, turan.dundar@ogr.deu.edu.tr.

** Dr. Öğr. Üyesi, Dokuz Eylül Üniversitesi, İşletme Fakültesi, İktisat Bölümü, ORCID: 0000-0002-8434-8447, mehmet.beyzatlar@deu.edu.tr. 


\title{
AIR TRANSPORTATION AND URBANIZATION: CONNECTEDNESS EVIDENCE IN TURKEY AND FOUR MOST POPULATED COUNTRIES OF THE EUROPE
}

\begin{abstract}
The main aim of this paper is to demonstrate the dynamic interaction between urbanization and transportation. This paper provides an empirical evaluation of dynamic connectedness between urbanization and air transportation mobility. The empirical part uses annual time-series data for Turkey, Germany, France, Italy, and United Kingdom according to data availability for the period 1970-2019. The variable of interest includes the share of urban population as urbanization, and the mobility of freight and passenger with air transportation. Urbanization and transportation measures have been obtained from World Bank statistical database. Dynamic connectedness approach provides various spillover parameters such as, from one to all, from all to one, net, pairwise, and total connectedness indexes, which might bring different perspective to the determination of the linkage between air transportation mobility and urbanization. Our findings show that air transportation is related to urbanization in terms of freight and passengers. According to the dynamic nature of transportation with urbanization and the spreading results, while transportation is receiver, urbanization is in a transmitter position. The fact that there is a transfer from urbanization to transportation is especially important in terms of the effectiveness of transportation policies in urban areas.
\end{abstract}

Keywords: Urbanization, Air transportation, Freight and passenger mobility connectedness, Turkey, Europe.

\section{GíRiş}

$\mathrm{Bu}$ makalenin amacı, kentleşme ile hava taşımacılığı arasındaki etkileşimi göstermektir. Dinamik bağlantılılık yöntemi kullanılarak yapılan ampirik analizlerde, hava yük ve yolcu taşımacılığı ile kentleşme arasındaki etki aktarım parametreleri elde edilmiştir. Çalışmada kullanılan veri setleri, 1970-2019 dönemi için Türkiye ile Avrupa'dan nüfus olarak ilk sıralarda yer alan Almanya, Birleşik Krallık, Fransa ve İtalya'yı içermektedir. Nüfusu yüksek olan ülkelerin seçilme amaçları arasında hem kentleşme hem de hava ulaşım ve taşımacılığının boyutları yer alırken, veri mevcudiyeti de dikkate alınmıştır.

Küreselleşme sürecinin gelişerek devam etmesiyle birlikte sosyal, ekonomik ve çevresel faktörlerde birtakım değişmeler meydana gelmektedir. Çeşitli ürün ve hizmetlerin, üretim faktörlerinin ve nüfusun hareketliliğini sağlayan ulaşım olanaklarının gelişmesiyle insanların yaşamak istediği alanlarda da farklılıklar görülmektedir. Bu farkl1l1kların oluşmasında birçok faktör gibi ulaşımın da rolü vardır. Ulaşım çeşitleri düşünüldügünde hava yolu ulaşımı diğer ulaşım çeşitlerine göre hem daha hızlı hem de daha güvenlidir. Bunun yanı sıra çok daha karmaşık, gelişmiş ve ileri teknolojik gereksinimleri bulunması nedeniyle de ulaşım yapısının genel durumu hakkında bilgiler sunar. Öte yandan kentleşme ile ilgi bilgileri kentsel nüfus ve kırsal nüfus üzerinden değerlendirmek kentleşme hakkında genel bir çerçeve çizmek için faydalı olacaktır. Kentsel ve kırsal nüfus oranı kavramları, 
Dünya Bankası kalkınma indikatörlerinden olan kent nüfusunun toplam nüfus içindeki yüzdesel sayısal değeri ve kırsal alanda yaşayan nüfusun toplam nüfus içerisindeki yüzdesel sayısal değeri olarak tanımlanmaktadır. Kentleşme değerlendirmeleri ve kentleşmeye bağlı değerlendirmeler yapılırken yaygın olarak bu istatistiklerden faydalanılmaktadır. Fakat literatürde yer alan çalışmaların kapsamı ülke içi ile sınırlı kalmaktadır. Bu çalışma, literatürdeki boşluğu doldurabilmek adına, kentleşme ve ulaşım ilişkisini ülkeler arası boyutta incelemektedir. Ulaşım; erişilebilirlik, mesafe ve bilgiyi temsil edebildiği için gelişmişlik göstergesi olarak da kabul edilir.

Tanımlamadan kaynaklanabilecek olası sorunların önüne geçmek için kentleşme kavramının genel kabul gören tanımları ve dinamiklerine değinmek gerekir. Dar anlamda kentleşme kırsal alanlardaki tarımsal istihdamın, hizmetler ve imalat sektörü ağırlıklı kentsel alanlara kayması olarak tanımlanabilir. Ancak geniş bir perspektiften bakıldığında kentleşmeyi etkileyen birçok faktör vardır ve sadece çalışan nüfus değil aynı zamanda çalışmayan ya da çalışamayacak durumda olan nüfus da bu alanlar arası geçişi yapmaktadır. Bu açıdan bakıldığı zaman kent; ekonomik açıdan, sosyal açıdan ve sunduğu olanaklar açısından (ulaşım, iletişim, altyapı, eğitim, sağlık vb.) kırsal alandan daha fazlasını sunan yeri temsil etmektedir. $\mathrm{Bu}$ yönüyle toplumsal, sosyal, kültürel ve politik unsurları da içerir. Sunduğu olanaklar ile kentleşme kavramının tanımsal bir gereği olan kent nüfusunun değerini belirleyen niteliksel ve niceliksel değişkenler ortaya çıkmaktadır. Ülke içi yerleşiklerinin yapısal değişikliklere vermiş oldukları bölgesel tepkiler ve bu tepkilerin bir sonucu olan iç ve dış göç, doğal nüfus artışının belirleyicileri olan doğum ve ölümler, son olarak bu nedenler dışında ülkeye dişardan gelen ve ülkeden dışarıya çıkan nüfusun kentsel alandaki nüfusta meydana getirdiği değişimler kentleşme kavramının dinamiklerini oluşturmaktadır. Bu iki alan dışında erişilebilirlik kavramının tanımlamasının yapılması da kentsel ve kırsal bölge tanımı kadar elzemdir. Erişilebilirlik, insanları, pazarları ve kaynakları birbirine bağlamanın bir yolu olarak ulaşımın önemini vurgular. Mesafe, bilgi ve ulaşım olanakları bir insanın genel yaşantısına, ürün ve hizmetlere olan talebine, tüketim alışkanlıklarına doğrudan ve dolaylı olarak etki eder. Erişilebilirlik açısından kentsel alanlar, ihtiyaçlarını karşılamak için daha hızlı ulaşım yöntemlerine ihtiyaç duyar. Kentleşme çoğunlukla yaşam kalitesini arttıran bir etmen iken aynı zamanda kentleşme ve kentleşmenin paydaşlarından biri olan ulaşım bazen yapısal veya geçici çevre sorunlarına da yol açabilmektedir. (Kojima, 1996; Sharma, 2003; Njoh, 2003; Antrop, 2004; Kotavaara, 2011; World Bank, 2021)

Bu çalışmanın geri kalanı şu şekilde şekillenmiştir: sonraki bölüm havayolu ulaşımının, taşımacılık kapsamında ve kentleşme bağlamında literatür taramasını kapsamakta. Türkiye ve Avrupa'dan seçilen dört ülkenin ulaşım ve kentleşme arasındaki dinamik yayılmalarını gözlemlemek için kullanılan veriler ve bağlantılılık yöntemi üçüncü bölümde sunulmaktadır. Ampirik sonuçlar dördüncü bölümde tartışılmış ve ardından son bölüm olarak sonuç notları verilmiştir. 
Dündar, T., Beyzatlar, M. A.

DEÜ SBE Dergisi, Cilt: 23, Özel Sayl

\section{LITERATÜR TARAMASI}

Kentleşme ile ulaşımın birbirini beslediğini savunan ve tarihsel süreci vurgulayan çalışmalar teorik olarak ulaşım ve kentleşme arasındaki köprünün anlaşılmasını sağlar ve bu ilişkinin önemini ortaya koymaktadırlar (Krugman, 1991; Sharma, 2003; Daniere, 1999; Njoh, 2003; Antrop, 2004; Motamed vd., 2014). Krugman (1991) sanayi ve demiryolu öncesi toplumunun çoğunluğunun tarımla uğraştığını, imalat ve ticaretin payının ise ölçek ekonomileri bağlamında küçük olduğunu belirtmiştir. Yine aynı çalışmada, taşımacılık maliyetlerinin ölçek ekonomilerindeki rolüne vurgu yapılmıştır ve yüksek taşımacılık maliyetlerinin ekonomik olarak zayıf getirilere neden olacağı söylenmiştir. Bir diğer önemli tespit ise, daha yüksek getiri ekonomisine geçiş yapılabilmesinin ulaşımdaki yeniliklerle mümkün olacağıdır. Daniere (1999)'a göre benzer biçimde gelişmekte olan ülkelerde ulaşım kentsel yaşamın sürdürülebilirliği konusunda etkilidir. Kentleşme ile daha geniş alanlara yerleşilmekte ve kentleşme geliştirilmektedir. Kasraian vd. (2020) Kanada için transit ulaşımdaki iyileşmelerin erişilebilirlik kapsamında önemine vurgu yaparak kentleşmeyi nüfus anlamında ve iş bulma konusunda olumlu yönde etkilendiğini savunmuştur. Fakat kentleşmenin ulaşımdan çok kendisine yakın nüfus merkezleriyle ilişkili olduğunu çünkü erişilebilirlik etkisinin ulaşımdaki iyileştirmeler ve negatif dışsallıklar nedeniyle kentleşme üzerindeki etkisinin azalma eğiliminde olacağını söylemiştir. Antrop (2004) kentleşme sürecinin önce büyük şehirleri etkilediğini, daha sonra kırsalı etkilediğini ve kentleşme ile ilgili ulaşım altyapısının kent ve kırsal arasındaki ilişkiyi tanımladığını savunur. Zenou (2011) kırsal ve kentsel bölgelerde ücret ve üretkenlik farklılığı, ulaşım maliyetlerinin çok yüksek esnekliğe sahip olması koşullarında ulaşım maliyetlerinin düşürülmesinin nüfusun kırsal bölgelerden kentsel bölgelere doğru akış gösterebileceğini belirtmiştir. Ulaşım maliyetlerinin düşmesi ile daha çok insan kentlerde çalışmaya istekli olur ve bu durum ücretlerde önceki dönemlere göre azalma olmasına neden olabilir. Motamed vd. (2014) kentleşmenin kentsel nüfusa dayalı bir tanım olduğunu vurgulayarak, ulaşım olanaklarının daha erken geliştiği yerlerde ekonomik kalkınmanın daha erken gerçekleşeceğini ve düşük maliyetli ulaşımın kentin büyümesini kolaylaştırdığını belirtmektedirler.

Kentleşme ve ulaşım arasındaki dinamik ilişkiyi inceleyen çalışmalar, değişkenler arasındaki ilişki, ilişkinin yönü ve kapsamı konusunda farklılaşmıştır. Goetz (1992) ulaşım ve kentleşme arasındaki ilişkinin var olup olmadığı yönündeki temel istatistiksel çalışmasında ulaşımın seviyesinin ileri ve daha teknolojik olan hava yolu ulaşımını taşınan yolcu sayısı üzerinden, kentleşmeyi ise istihdam ve kent nüfusu üzerinden değerlendirdiği çalışmasında bu ikili arasında pozitif bir ilişki olduğunu ortaya koymuştur. Arvin vd. (2015) kentleşme ile hava taşımacılığ arasında ve kentleşme ile hava ulaşımı kanalıyla taşınan yolcu sayısı arasında çift yönlü Granger-nedenselliği bulmuştur. Amin vd. (2020) Avrupa ülkeleri için yaptıkları çalışmalarında kentleşmeden ulaşımın neden olduğu $\mathrm{CO} 2$ emisyonuna ilişkin tek taraflı daha büyük bir nedensellik ilişkisi bulmuşlardır. Shahbaz vd. 
(2017) Pakistan için çeyreklik veriler üzerinden yaptıkları çalışmalarında kentleşmenin ulaşımın Granger nedeni olduğunu bulmuşlardır. Maparu ve Mazumder (2017) genel literatürün aksine kentleşme ile hava taşımacılığı arasında nedensellik bulmamış, ancak su yolu ulaşımı kapsamında liman altyapısından kentleşmeye tek taraflı bir nedensellik bulmuştur. Liu ve Su (2021) ilişkisel olarak ulaşım altyapısının kentleşme üzerinde olumlu etkiler yaratacağını söylemiştir. Çin için yaptıkları çalışmalarının inceledikleri zaman aralığındaki tüm periyotlar için nedensellik testi sonucunun anlamsız olduğunu ve nedensellik bulamadıklarını belirtmişlerdir. Fakat belirli periyotlarda yaptıkları inceleme sonucunda ulaşımdan kentleşmeye doğru tek yönlü bir nedensellik bulmuşlardır. Wang vd. (2020) Tibet Platosu için yaptıkları çalışmalarında kentleşmenin mekânsal yapısı üzerine eğilmişlerdir. Onlara göre Tibet Platosu için kentleşmenin mekânsal yapısını etkileyen ana etmenler ulaşım ve topografyadır ayrıca ulaşım ağının planlanması ve inşası kentleşmeyi teşvik eder.

\section{VERİ SETİ VE BAĞLANTILILIK YÖNTEMI}

$\mathrm{Bu}$ çalışma, Türkiye ve nüfus bakımından Avrupa'daki en büyük dört ülkenin (Almanya, Birleşik Krallık, Fransa ve İtalya) 1970-2019 yılları arasında havayolu taşımacılığı ile kentleşme arasındaki ülke içi ve ülkeler arası dinamik bağlantılılık ilişkilerini sorgulamayı amaçlamaktadır. Bu çalışmada kullanılan veriler Dünya Bankası istatistiksel veri bankasından alınmış olup havayolu ile taşınan yük olarak milyon-ton (bundan sonraki bölümlerde AIRF olarak kullanılacaktır), havayolu ile taşınan yolcu sayısı milyon (çalışmanın geri kalanında AIRP olarak karşımıza çıkacaktır) ve kentleşmenin nüfus bakımından gösterimi olan toplam nüfus içindeki kentli sayısının yüzdesel değeri (URB olarak kullanılacaktır) olarak kullanılmıştır. Kullanılan veriler frekans olarak yıllık olup, Tablo 1 bu çalışmada kullanılan değişkenlerin tanımlayıcı istatistiklerini göstermektedir.

Tablo 1: Tanımlayıcı İstatistikler

\begin{tabular}{llrrrr}
\hline Değişken & Ülke & Ortalama & Medyan & Minimum & Maksimum \\
\hline AIRF & Almanya & 4829,30 & 5604,60 & 484,50 & 10187,72 \\
& Birleşik Krallık & 4047,21 & 4794,35 & 516,90 & 7618,10 \\
& Fransa & 3694,49 & 4124,80 & 474,60 & 6624,89 \\
& İtalya & 984,76 & 1009,19 & 275,20 & 1748,41 \\
& Türkiye & 807,49 & 208,45 & 4,60 & 6815,51 \\
\hline \multirow{2}{*}{ AIRP } & Almanya & 50,83 & 33,57 & 6,50 & 117,22 \\
& Birleşik Krallık & 64,59 & 57,58 & 15,67 & 165,39 \\
& Fransa & 39,45 & 37,10 & 9,11 & 71,29 \\
& İtalya & 21,67 & 23,31 & 6,74 & 37,83
\end{tabular}


Dündar, T., Beyzatlar, M. A.

DEÜ SBE Dergisi, Cilt: 23, Özel Sayl

\begin{tabular}{llrrrr} 
& Türkiye & 22,89 & 7,31 & 1,04 & 115,60 \\
\hline URB & Almanya & 74,48 & 73,82 & 72,27 & 77,38 \\
& Birleşik Krallık & 79,32 & 78,49 & 77,03 & 83,65 \\
Fransa & 75,49 & 74,83 & 71,06 & 80,71 \\
İtalya & 67,27 & 66,90 & 64,27 & 70,74 \\
& Türkiye & 58,97 & 61,86 & 38,23 & 75,63
\end{tabular}

AIRF: Havayolu Yük Taşımacılığı; AIRP: Havayolu Yolcu Taşımacılığı; URB: Kentleşme.

$\mathrm{Bu}$ çalışmada kullanılan zamanla değişen vektör otoregresif (TVP-VAR) dinamik bağlantılılık yaklaşımı, Diebold ve Yılmaz $(2012$, 2014) yönteminin geliştirilmiş versiyonu olarak Antonakakis vd. (2020) tarafından kavramsallaştırılan metodoloji kapsamındaki denklemler üzerinden takip edilmiştir. Çalışmada yer alan denklem (15) doğrultusunda, genelleştirilmiş tahmin hata varyans ayrıştırmalarına (GFEVD) dayalı toplam bağlantılılık endeksi (TBE) şu şekilde formüle edilmektedir:

$$
T B E_{t}(H)=\frac{\sum_{i, j=1, i \neq j}^{m} \widetilde{\varphi}_{i j, t}(H)}{\sum_{i, j=1}^{m} \widetilde{\varphi}_{i j, t}(H)} \times 100
$$

Toplam aktarılan bağlantılılık (TAB), çalışmada yer alan denklem (16), her bir değişkenin diğer tüm değişkenlere yayılımı ( $i$ den $j$ lere) olarak aşağıdaki şekilde formüle edilmektedir:

$$
T A B_{i \rightarrow j, t}(H)=\frac{\sum_{j=1, i \neq j}^{m} \widetilde{\varphi}_{j i, t}(H)}{\sum_{j=1}^{m} \widetilde{\varphi}_{j i, t}(H)} \times 100
$$

Toplam gelen bağlantıl111k (TGB), çalışmada yer alan denklem (17), diğer tüm değişkenlerden toplu olarak her bir değişkene yayılım ( $j$ lerden $i$ ye) aşağıdaki gibi formüle edilmektedir.

$$
T G B_{i \leftarrow j, t}(H)=\frac{\sum_{j=1, i \neq j}^{m} \widetilde{\varphi}_{i j, t}(H)}{\sum_{i=1}^{m} \widetilde{\varphi}_{i j, t}(H)} \times 100
$$

Net toplam yönsel bağlantılılık (NET), çalışmada yer denklem (18), alan toplam dışa aktarılan ve toplam gelen bağlantılılık parametreleri arasındaki fark olarak șu șekilde formüle edilebilir.

$$
N E T_{i, t}=T A B_{i \rightarrow j, t}(H)-T G B_{i \leftarrow j, t}(H)
$$

Eğer $i$ değişkeni etkilendiğinden daha fazla etkiliyorsa $N E T_{i, t}$ pozitif, etkilediğinden daha fazla etkileniyorsa da $N E T_{i, t}$ negatif değer alır.

Son olarak, değişkenler arasındaki ikili ilişkileri incelemek için net toplam yönsel bağlantılılık, çalışmada yer alan denklem (19), şu şekilde formüle edebiliriz.

$$
N T B Y_{i j}(H)=\left(\tilde{\varphi}_{j i t}(H)-\tilde{\varphi}_{i j t}(H)\right) x 100
$$


Burada $N T B Y_{i j}(H)$ pozitif değer alırsa $i$ değişkeni $j$ üzerinde baskın, $N T B Y_{i j}(H)$ negatif değer alırsa da $j$ değişkeni $i$ üzerinde baskı durumdadır.

\section{BULGULAR}

Dinamik bağlantıl1lık yönteminden önce, önemli bir adım, değişkenlerin durağanlık özelliklerini kontrol etmektir. Durağanlık özelliklerini kontrol etmek için, Perron (1997) tarafından geliştirilen ve yapısal kırılmaları dikkate alan birim kök testi uygulanmıştır. Büyük zaman boyutuna sahip değişkenler genellikle ekonomik, politik ve mali krizler vb. nedenlerle oluşabilecek yapısal kırılmalar şeklinde dış şoklara maruz kalabilmektedir. Geleneksel birim kök testleri bu tür yapısal kırılmaları göz ardı eder ve bu nedenle sonuçlar yanıltıcı olabilir. Bu durumun üstesinden gelmek için icra edilen yapısal kırılmalı birim kök test sonuçları Tablo 2 'de sunulmuştur.

Tablo 2: Birim Kök Test Sonuçları

\begin{tabular}{lcccccc}
\hline & \multicolumn{2}{c}{ AIRF } & \multicolumn{2}{c}{ AIRP } & \multicolumn{2}{c}{ URB } \\
\hline & t-ist. & Kırılma Yılı & t-ist. & Kırılma Yılı & t-ist. & Kırılma Yılı \\
\hline Almanya & $-11,161^{* * *}$ & 2011 & $-6,427 * * *$ & 2002 & $-9,648^{* * * *}$ & 1993 \\
Birleşik Krallık & $-7,696^{* * * *}$ & 1996 & $-5,948^{* * *}$ & 1995 & $-6,343^{* * * *}$ & 1996 \\
Fransa & $-12,931^{* * *}$ & 2009 & $-6,969 * * *$ & 1995 & $-7,804 * * *$ & 1991 \\
İtalya & $-12,833^{* * *}$ & 2009 & $-9,982^{* * *}$ & 2002 & $-7,987^{* * *}$ & 2002 \\
Türkiye & $-7,003^{* * *}$ & 2006 & $-6,552^{* * *}$ & 2006 & $-10,786^{* * * *}$ & 2005 \\
\hline
\end{tabular}

Not: Testler logaritmik birinci fark serilerine uygulanmıştır. Testlerin boş hipotezi, serinin (durağan olmadığı) birim kök içerdiğidir. ${ }^{* * *}$, serinin boş hipotezinin yüzde 1 istatistiksel anlamlılık düzeyinde reddedildiğini gösterir. Testler için asimptotik tek taraflı $\mathrm{p}$ değerleri Vogelsang (1993) üzerinden değerlendirilmeye alınmıştır.

Yapısal kırılmalı birim kök test sonuçlarına göre tüm değişkenler seviyede durağan değil ancak ilk farkta durağan oldukları bulunmuştur. Yapısal kırılmaları dikkate almayan ve iki yapısal kırılmalı testler de benzer sonuçlar içerdiğinden çalışmada yer verilmemiştir. Bu nedenle, bağlantılılık analizleri için gerekli şartları sağlaması bakımından tüm değişkenlerin logaritmik birinci fark serilerinin kullanılması uygundur. Buradan hareketle, havayolu yük ve yolcu taşımacılığı ile kentleşme arasındaki bağlantılılık parametreleri sırasıyla Tablo 3 ve 4 üzerinden incelenebilir. İlk olarak genel sonuçlar göz önüne alındığında, Toplam Bağlantılılık Endeksi'nin (TBE) havayolu yük taşımacılığı ile kentleşme arasında yüzde 75, havayolu yolcu taşımacılığı ile kentleşme arasında ise yüzde 78 seviyelerinde olduğu görülmektedir. Bu sonuçlara göre havayolu yük ve yolcu taşımacıllğı ve kentleşme arasında ortalamanın üzerinde seyreden karşı1ıklı bağlantılılığa ulaşı1mıştır. 
Grafik 1(a) incelendiğinde, TBE'nin 1970-2019 örneklem dönemi boyunca havayolu yük taşımacılığ 1 ve kentleşme arasında yüzde 60 ila 80 arasında değişirken, 1970'lerin ortalarında ulaştığı yüzde 80 seviyelerinde başlayan negatif trendle birlikte 2010'lu yılların başında yüzde 65'ler seviyesine gerilemiş ve 2015 sonrası yine aynı seviyelere sıçrama yaptığı görülebilmektedir. Grafik 1(b)'den görüldüğü üzere havayolu yolcu taşımacıllığı ve kentleşme arasında ise yüzde 60 ila 85 arasında değişen bir seyir izlenmektedir. Ancak burada, 2010'lu yılların başında daha kısa süren ve limitli bir düşüş ve ardından yüksek bir toparlanma süreci ile en yüksek seviyelere ulaşma dikkati çekmektedir. Her iki bağlantılılık analizlerinde dikkati çeken negatif trend sürecini taçlandıran azalışlar, 2007-2008 finansal kriz sonrasına tekabül etmekte, ancak bu süreçte havayolu yolcu taşımacıllı̆̆ ve kentleşme arasındaki bağlantılılığın havayolu yük taşımacılığı ve kentleşme arasındaki bağlantıl1lığa göre nispeten daha az etkilendiği görülmektedir.

Grafik 1: Toplam Bağlantılılık Endeksi (TBE)

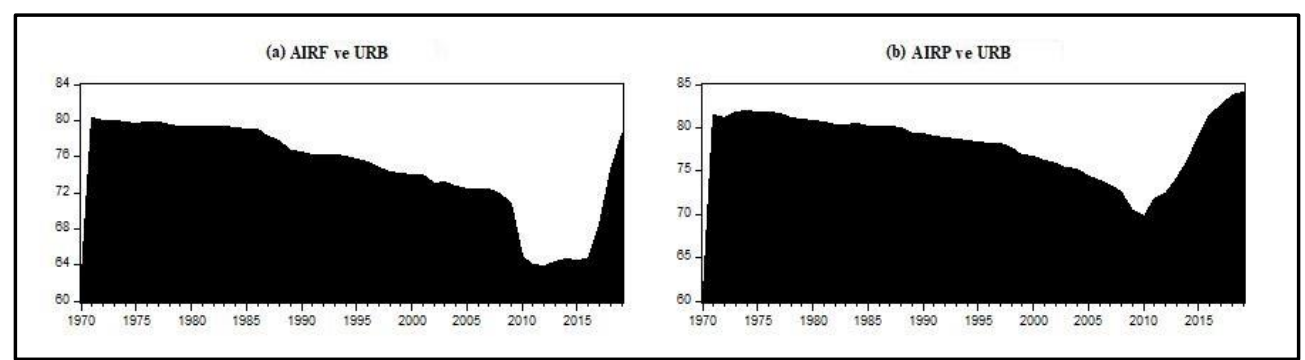

Not: AIRF: Havayolu Yük Taşımacılığı; AIRP: Havayolu Yolcu Taşımacılığı; URB: Kentleşme.

Bağlantılılık analizlerini içeren Tablo 3 ve 4 çeşitli parametreleri içermektedir. Bu parametreler, Antonakakis vd. (2020) çalışmasına atıf yapılan formüller bağlamında takip edilebilmekte ve sütundan satıra yönlü olarak okunması gerekmektedir. Tablo 3 üst panel dikkatli bir biçimde incelendiğinde havayolu yük taşımacılığı açısından en yüksek aktarım yüzde 76,86 ile Almanya kökenli iken hemen ardından yüzde 72,72 ila Türkiye ve yine yüksek sayılabilecek seviyeyle üçüncü sırada Fransa gelmektedir. Birleşik Krallık ve İtalya ise nispeten düşük seviyelerde aktarım göstermektedirler. Gelen tarafında ise yüzde 80,88 ile yine Almanya ilk sırada yer alırken bu kez ikinci sırayı yüzde 79,39 ile Fransa ve üçüncü sırayı yüzde 76,93 ila Türkiye almaktadır. Birleşik Krallık ve İtalya ise bu kez yüzde 60 üzerinde, nispeten yüksek oranlarda seyretmektedir. Karşılıklı değerlendirilmesi gereken bu parametrelerin oluşturduğu toplam yönsel yani net bağlant1l1l1k incelendiğinde tüm havayolu yük taşımacılığ daha yüksek oranda bağlantılılığa maruz kaldığını göstermektedir. Burada yüzde 39,51 ile Birleşik Krallık ilk sırada yer alırken, yüzde 30,45 ile İtalya ikinci ve yüzde 16,88 ile Fransa üçüncü sırada yer almaktadır. Almanya ve Türkiye ise yüzde 4 seviyelerinde yani düşük oranlarda aktarım almaktadırlar. Özetle Almanya ve Türkiye'nin havayolu yük taşımacılığı diğer tüm etkenlerden aktarım alan tarafta 
olmalarına rağmen düşük oranlarda seyretmektedirler. Havayolu yük taşımacılığ 1 bakımından ülkelerin net bağlantılılık süreçleri 1970-2019 dönemi kapsamında görsel olarak Grafik 2 üzerinden incelenebilmektedir.

Tablo 3: Bağlantıl11ık Parametreleri (AIRF-URB)

\begin{tabular}{|c|c|c|c|c|c|c|}
\hline & AIRF-A & AIRF-B & AIRF-F & AIRF-İ & AIRF-T & TGB \\
\hline AIRF-A & 19,120 & 3,417 & 11,166 & 6,005 & 8,953 & 80,880 \\
\hline AIRF-B & 7,825 & 34,754 & 15,379 & 5,726 & 2,504 & 65,246 \\
\hline AIRF-F & 16,359 & 4,674 & 20,612 & 4,528 & 10,076 & 79,388 \\
\hline AIRF-İ & 12,224 & 4,929 & 12,569 & 38,703 & 9,132 & 61,297 \\
\hline AIRF-T & 6,493 & 1,430 & 6,946 & 4,593 & 23,072 & 76,928 \\
\hline URB-A & 10,218 & 2,392 & 3,454 & 4,064 & 8,471 & 75,722 \\
\hline URB-B & 3,552 & 2,881 & 1,424 & 1,474 & 6,361 & 72,230 \\
\hline URB-F & 5,911 & 1,180 & 2,616 & 1,077 & 9,324 & 77,322 \\
\hline URB-İ & 7,488 & 3,946 & 3,553 & 2,662 & 9,051 & 79,084 \\
\hline URB-T & 6,785 & 0,883 & 5,402 & 0,712 & 8,849 & 76,513 \\
\hline TAB & 76,856 & 25,732 & 62,510 & 30,842 & 72,720 & \\
\hline \multirow[t]{2}{*}{ NET } & $-4,024$ & $-39,514$ & $-16,878$ & $-30,455$ & $-4,208$ & \\
\hline & URB-A & URB-B & URB-F & URB-İ & URB-T & TGB \\
\hline AIRF-A & 10,263 & 8,153 & 11,045 & 10,799 & 11,079 & 80,880 \\
\hline AIRF-B & 2,176 & 13,282 & 8,884 & 5,634 & 3,836 & 65,246 \\
\hline AIRF-F & 4,515 & 10,188 & 9,523 & 9,596 & 9,932 & 79,388 \\
\hline AIRF-İ & 5,471 & 1,302 & 3,831 & 6,224 & 5,615 & 61,297 \\
\hline AIRF-T & 12,132 & 8,824 & 13,224 & 12,285 & 11,000 & 76,928 \\
\hline URB-A & 24,278 & 11,716 & 13,414 & 12,668 & 9,325 & 75,722 \\
\hline URB-B & 8,833 & 27,770 & 22,197 & 12,915 & 12,593 & 72,230 \\
\hline URB-F & 12,775 & 14,269 & 22,678 & 12,424 & 17,745 & 77,322 \\
\hline URB-İ & 10,451 & 16,990 & 13,992 & 20,916 & 10,950 & 79,084 \\
\hline URB-T & 10,474 & 11,158 & 16,535 & 15,715 & 23,487 & 76,513 \\
\hline TAB & 77,090 & 95,883 & 112,643 & 98,259 & 92,076 & \\
\hline NET & 1,368 & 23,653 & 35,320 & 19,175 & 15,563 & \\
\hline
\end{tabular}

Not: AIRF: Havayolu Yük Taşımacılığı, URB: Kentleşme, A: Almanya, B: Birleşik Krallık, F: Fransa, İ: İtalya, T: Türkiye, TBE: Toplam Bağlantılılık Endeksi, TAB: Toplam 
Dündar, T., Beyzatlar, M. A. DEÜ SBE Dergisi, Cilt: 23, Özel Sayl

Aktarılan Bağlantılılık, TGB: Toplam Gelen Bağlantılılık, NET: Net Toplam Yönsel Bağlantılılık (NET=TAB - TGB).

Grafik 2 detaylı bir biçimde incelendiğinde Birleşik Krallık daimi aktarım toplamaktayken, diğer ülkeler dalgalı seyir izlemektedir. Türkiye özelinde 1990 ve 2017 yılları hem öncesi ve sonrası olarak hem de 1990-2017 dönemi olarak değerlendirilebilir. Almanya'nın düşük yüzdeli seyri tüm döneme yayılırken Fransa ve İtalya başta olmak üzere tüm ülkelerin 2007-2008 finansal kriz sonrası döneme özellikle de 2010 yılı sonrasına verdikleri tepkiler dikkati çekmektedir.

Grafik 2: AIRF Net Bağlantıl1lık (AIRF-URB)

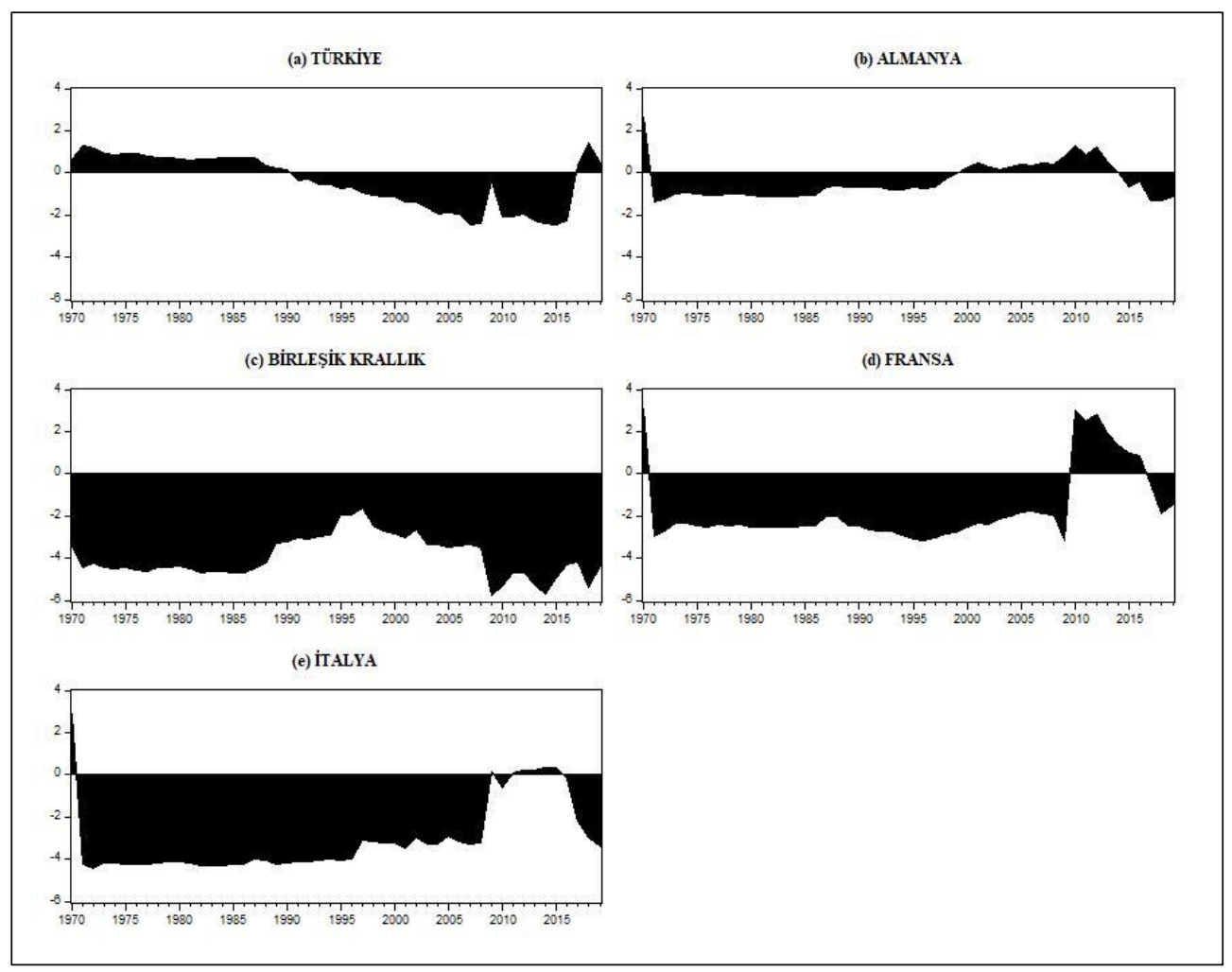

Tablo 3'ün alt kısımdaki kentleşme parametrelerine bakıldığında ise en yüksek aktarım yüzde 112,64 ile Fransa kaynaklı olurken onu sirasıyla yüzde 98,26 ile İtalya, yüzde 95,88 ile Birleşik Krallık, yüzde 92,08 ile Türkiye ve son olarak yüzde 77,09 ile Almanya izlemektedir. Gelen tarafinda ise oranlar yüzde 72-79 bandında yakın seyretmektedir. Siralama ise İtalya, Fransa Türkiye, Almanya ve Birleşik Krallık şeklindedir. Net bağlantılılık parametreleri değerlendirildiğinde ise kentleşmenin ekseriyetle aktarıcı olduğu görülmektedir. Fransa yüzde 35,32 ile belirgin bir biçimde ön plana çıkmaktadır. Onu yüzde 23,65 ile Birleşik Krallık izlerken, İtalya ve Türkiye ise yüzde 20'nin altında, Almanya ise yüzde 1,37 ile en 
düşük seviyede aktarım göstermektedir. Kentleşme açısından ülkelerin net bağlantılılık süreçleri 1970-2019 dönemi kapsamında görsel olarak Grafik 3 üzerinden incelenebilmektedir. Bu grafiklerde, Türkiye, Birleşik Krallık ve Fransa sadece ilk yıl hariç daimi aktarıcı özellik göstermekteyken, İtalya buna ek olarak 2010 sonrası aktarım alan rol oynamış, Almanya'nın ise tüm dönem süresince düşük yüzdeli ve dalgalı seyir izlediği görülebilmektedir. Grafik 2'deki gibi 2007-2008 finansal kriz sonrası döneme olan tepkinin yine 2010 yılı gibi ortaya çıktığı görülmektedir. Almanya ve İtalya'da pozitif bölgeden negatif bölgeye geçiş olarak yansıyan süreç diğer üç ülkede aynı bölgede yüzdesel azalış olarak görülmektedir.

Grafik 3: URB Net Bağlantılılık (AIRF-URB)

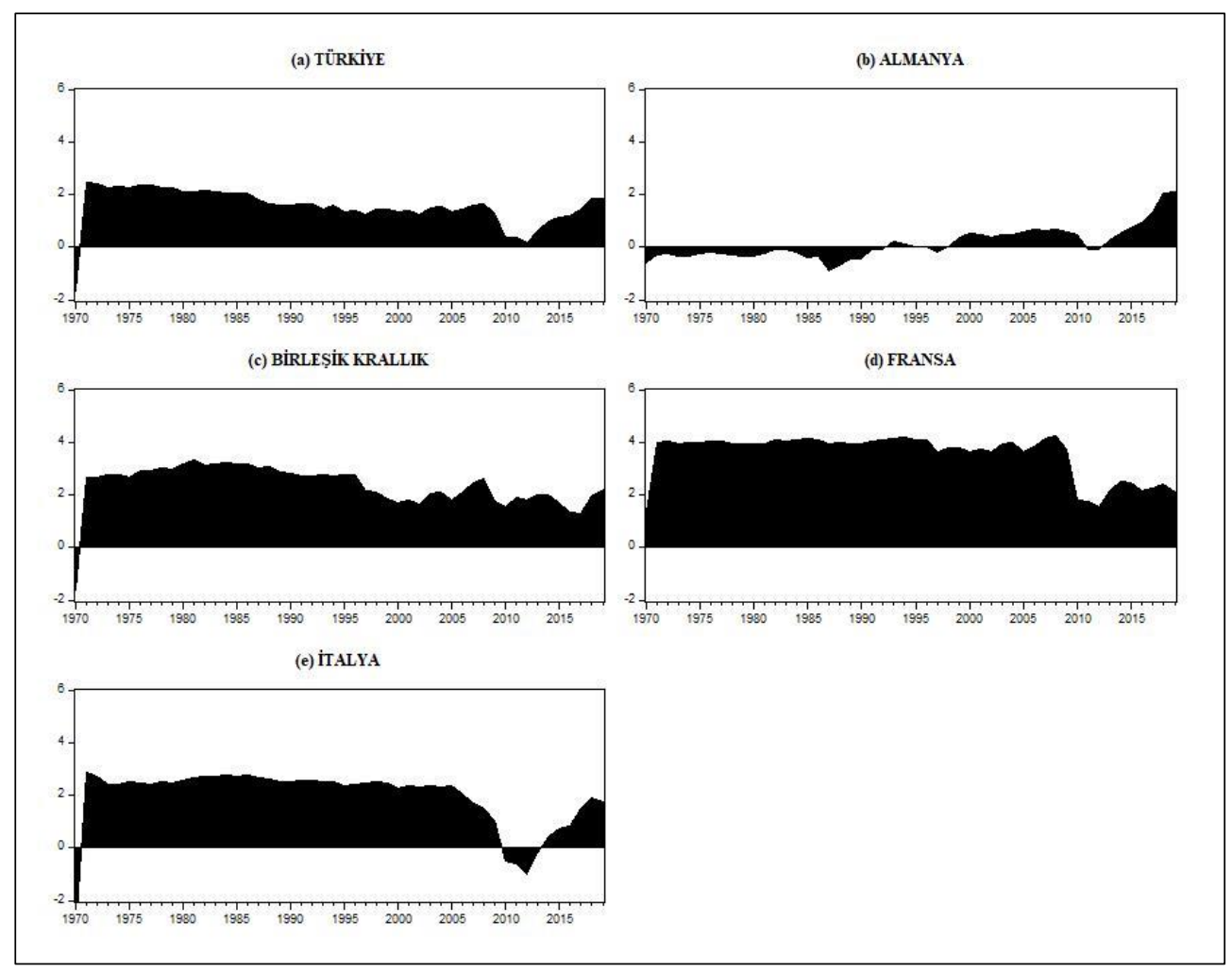

Havayolu yolcu taşımacılığı ve kentleşme arasındaki yayılma parametrelerini içeren Tablo 4'ün üst kısmı incelendiğinde havayolu yolcu taşımacıllğı açısından en yüksek aktarım yüzde 92,80 ile yine Almanya kökenli iken hemen ardından yüzde 77,17 ile bu kez Birleşik Krallık gelirken, Türkiye ise yüzde 49,61 ile üçüncü sırada gelmektedir. Fransa ve İtalya ise sırasılyla yüzde 35,20 ve 16,69 ile son iki sırayı paylaşmışlardır. 
Dündar, T., Beyzatlar, M. A.

DEÜ SBE Dergisi, Cilt: 23, Özel Sayl

Tablo 4: Bağlantıl11ık Parametreleri (AIRP-URB)

\begin{tabular}{|c|c|c|c|c|c|c|}
\hline & AIRP-A & AIRP-B & AIRP-F & AIRP-İ & AIRP-T & TGB \\
\hline AIRP-A & 20,087 & 7,336 & 1,715 & 3,368 & 4,061 & 79,913 \\
\hline AIRP-B & 9,232 & 19,298 & 3,665 & 1,450 & 7,007 & 80,702 \\
\hline AIRP-F & 9,003 & 11,799 & 20,530 & 1,952 & 6,984 & 79,470 \\
\hline AIRP-İ & 11,092 & 8,512 & 3,365 & 29,812 & 4,628 & 70,188 \\
\hline AIRP-T & 14,879 & 5,834 & 3,844 & 2,402 & 19,480 & 80,520 \\
\hline URB-A & 9,244 & 13,670 & 6,304 & 2,411 & 5,004 & 76,589 \\
\hline URB-B & 11,452 & 7,807 & 1,314 & 0,950 & 3,880 & 73,332 \\
\hline URB-F & 11,132 & 6,353 & 3,891 & 1,352 & 5,955 & 80,628 \\
\hline URB-İ & 8,134 & 11,102 & 4,131 & 1,723 & 5,465 & 80,531 \\
\hline URB-T & 8,630 & 4,753 & 6,970 & 1,083 & 6,629 & 78,213 \\
\hline TAB & 92,800 & 77,165 & 35,199 & 16,691 & 49,614 & \\
\hline \multirow[t]{2}{*}{ NET } & 12,887 & $-3,538$ & $-44,271$ & $-53,498$ & $-30,906$ & \\
\hline & URB-A & URB-B & URB-F & URB-İ & URB-T & TGB \\
\hline AIRP-A & 8,932 & 16,719 & 16,688 & 8,077 & 13,017 & 79,913 \\
\hline AIRP-B & 6,059 & 14,844 & 14,960 & 9,896 & 13,590 & 80,702 \\
\hline AIRP-F & 9,387 & 6,930 & 9,693 & 13,244 & 10,479 & 79,470 \\
\hline AIRP-İ & 11,568 & 6,867 & 8,754 & 7,468 & 7,934 & 70,188 \\
\hline AIRP-T & 6,736 & 15,110 & 12,488 & 7,596 & 11,632 & 80,520 \\
\hline URB-A & 23,411 & 8,355 & 10,389 & 12,996 & 8,215 & 76,589 \\
\hline URB-B & 5,708 & 26,668 & 19,115 & 11,321 & 11,785 & 73,332 \\
\hline URB-F & 10,693 & 12,399 & 19,372 & 12,594 & 16,257 & 80,628 \\
\hline URB-İ & 10,030 & 15,242 & 14,214 & 19,469 & 10,491 & 80,531 \\
\hline URB-T & 9,117 & 10,360 & 17,413 & 13,258 & 21,787 & 78,213 \\
\hline TAB & 78,231 & 106,826 & 123,714 & 96,450 & 103,398 & \\
\hline NET & 1,643 & 33,493 & 43,086 & 15,918 & 25,185 & \\
\hline
\end{tabular}

TBE: 78.009

Not: AIRP: Havayolu Yolcu Taşımacılığı, URB: Kentleşme, A: Almanya, B: Birleşik Krallık, F: Fransa, İ: İtalya, T: Türkiye, TBE: Toplam Bağlantıllılı Endeksi, TAB: Toplam Aktarılan Bağlantılılık, TGB: Toplam Gelen Bağlantılılık, NET: Net Toplam Yönsel Bağlantılılık (NET=TAB - TGB). 
Aktarım alan tarafta ise yüzde 80 seviyelerinde birbirlerine epey yakın oranlarda Birleşik Krallık ve Türkiye ilk iki sırada yer alırken bu kez üçüncü ve dördüncü sırayı yüzde 79 seviyelerinde yine yakın oranlarda Almanya ve Fransa almaktadır. İtalya ise yüzde 70 seviyesinde yine son sırada yer almaktadır. Aktarımın iletim ve alım yüzdelerini karşılıklı değerlendirmeyi gerektiren net bağlantılılık parametreleri incelendiğinde Almanya hariç Türkiye ve diğer üç ülkenin havayolu yolcu taşımacılığı ölçümlerinin negatif yani aktarıma maruz kaldığını göstermektedir. Almanya ise yüzde 12,89 gibi bir oranla aktarım yapan tarafta yer almaktadır. Burada yani negatif grupta yüzde 53,50 ile İtalya, yüzde 44,27 ile Fransa, yüzde 30,91 ile Türkiye ve son olarak yüzde 3,54 gibi düşük bir yüzde ile Birleşik Krallık sıralaması görülmektedir.

Grafik 4: AIRP Net Bağlantıl11ık (AIRP-URB)

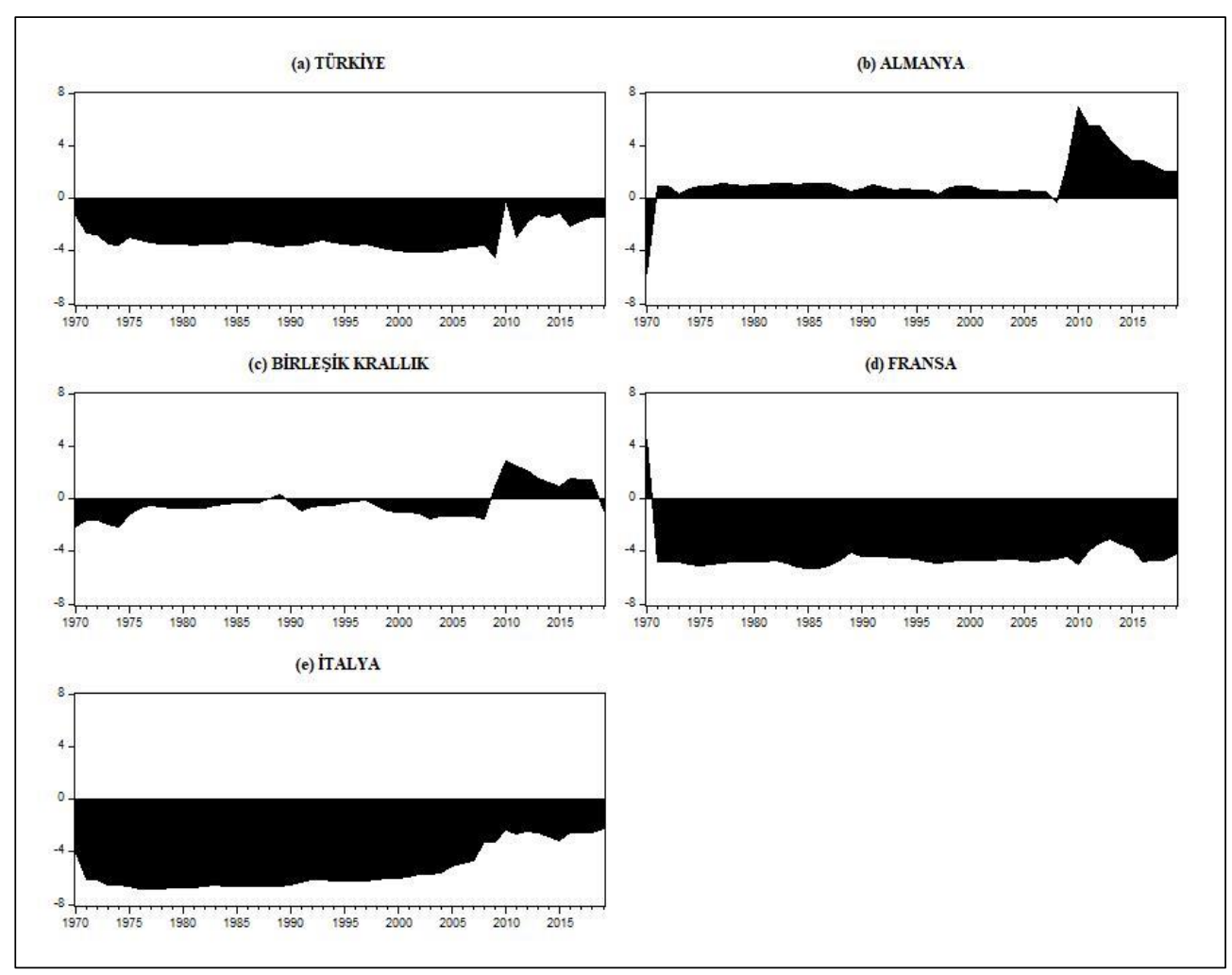

Havayolu yolcu taşımacılığı bağlamında ülkelerin net bağlantılılık süreçleri 1970-2019 dönemi kapsamında görsel olarak Grafik 4 üzerinden incelenebilmektedir. Türkiye, Fransa ve İtalya daimi aktarım alan bir yapı sergilerken Almanya ve Birleşik Krallık nispeten düşük yüzdeli ve dalgalı seyir izlemektedir. 2007-2008 finansal kriz etkileri yine görülmektedir. 
Tablo 4'ün alt kısımdaki kentleşme parametrelerine bakıldığında ise en yüksek aktarım yüzde 123,71 ile yine Fransa kaynaklı olurken onu sirasıyla yüzde 106,83 ile Birleşik Krallık, yüzde 103,40 ile Türkiye, yüzde 96,45 ile İtalya ve son olarak yüzde 78,23 ile yine Almanya izlemektedir. Gelen tarafinda ise ülkelerin parametreleri nispeten daha dar kapsamda, yüzde 73-80 aralığında seyretmektedir. Sıralama ise Fransa, İtalya, Türkiye, Almanya ve Birleşik Krallık şeklindedir. Net bağlantılılık parametreleri değerlendirildiğinde ise kentleşmenin tüm ülkelerde aktarıc1 rol oynadığı görülmektedir. Fransa yine yüzde 43,09 ile belirgin bir biçimde ön plana çıkmaktadır. Onu yüzde 33,49 ile Birleşik Krallık izlerken, Türkiye yüzde 25,19 ile üçüncü, İtalya ise yüzde 15,92 ile dördüncü sırayı almıştır. Son olarak Almanya yüzde 1,64 ile epey düşük seviyede aktarım göstermektedir.

Grafik 5: URB Net Bağlantıl11ık (AIRP-URB)

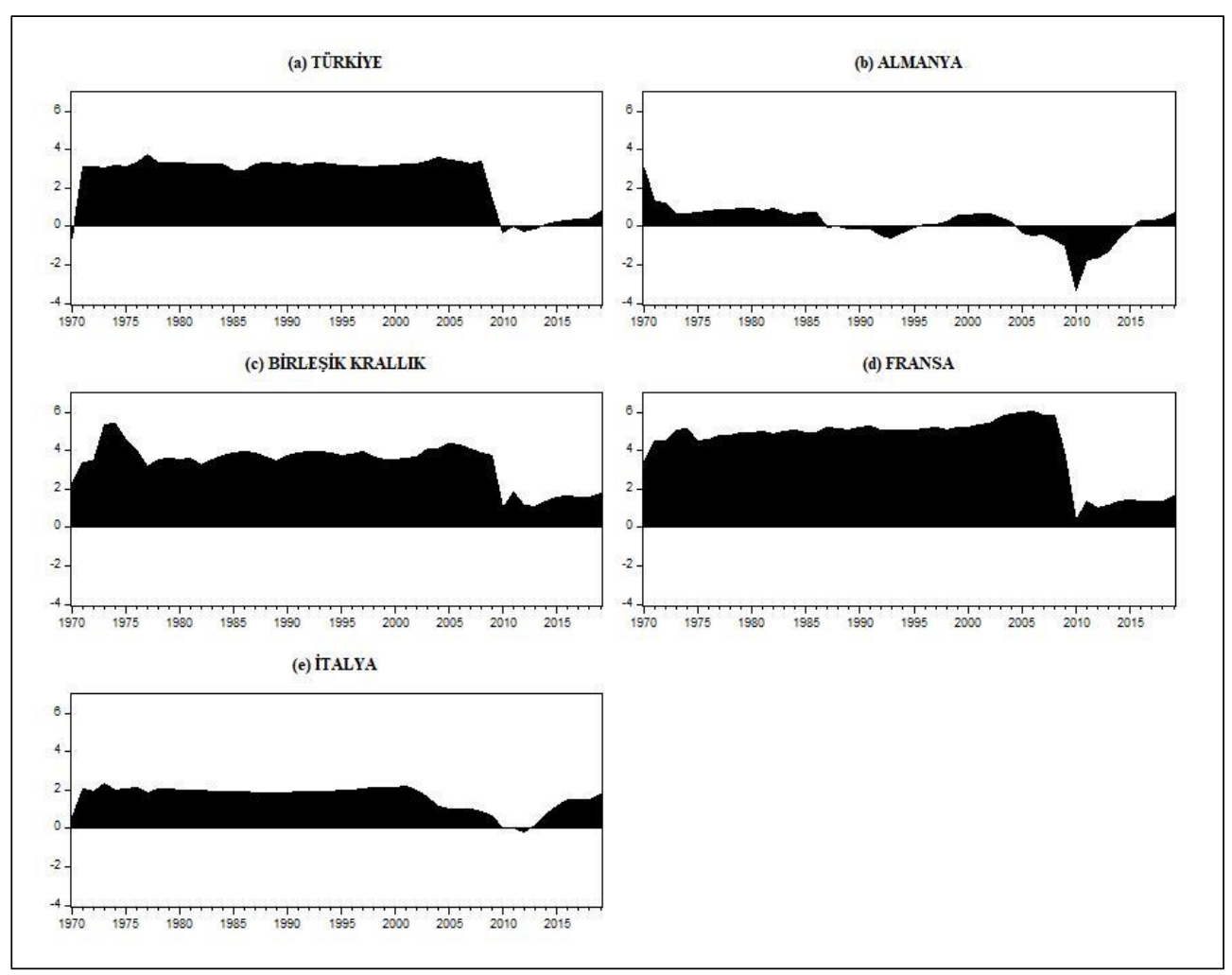

Kentleşme açısından ülkelerin net bağlantılılık süreçleri 1970-2019 dönemi kapsamında görsel olarak Grafik 5 üzerinden incelenebilmektedir. Bu grafiklerde, sadece Birleşik Krallık ve Fransa tüm dönemi kapsayacak şekilde daimi aktarıcı özellik göstermekteyken, Türkiye ve İtalya ise 2010 sonrası dönemde birkaç yıl aktarım alan bölgeye inmiş ve 2015 öncesi tekrar aktarıcı rolüne geri dönmüşlerdir. Almanya ise yine her analizde olduğu gibi dalgalı seyir izlemekte ancak tüm 
ülkelerde yine 2007-2008 finansal kriz etkileri bariz bir şekilde yüzdesel anlamda azalmayla karşılaşmıştır.

\section{SONUÇ}

Dinamik yayılma etki parametrelerini havayolu taşımacıllğ 1 ve kentleşme arasındaki bağlantılılı̆g 1 ortaya koyarken kullandığımız bu çalışma hem konuya ilişkin bakış açımıza yenilik getirmiş hem de literatüre katkı sağlamıştır. Hava taşımacılığı ve kalkınma göstergelerinin dinamik yayılma etkilerini gösteren çalışmamızın sonuçları bir önceki bölümde açıklanmış ve tablolaştırılmıştır. Sonuçlarımızın etkisini ve kapsamını değerlendirmek için genel bir özet yapmak faydalı olacaktır. İlk olarak Toplam Bağlantılılık Endeksi, AIRP ve URB için yüzde 75 civarı yüksek bir oranı gösterir iken aynı endeks paralel olarak AIRF ve URB için yüzde 78 değerlerini bulmuştur. AIRP ve URB arasındaki yayılım göstergelerine bakıldığında seçili tüm ülkelerde kentleşmenin iletici olduğu gözükürken Almanya hariç diğer tüm ülkelerde havayolu yolcu göstergesinin alıcı olduğu belirtilmektedir. Almanya'nın kendine özgü durumu kalkınma kavramı düşünüldüğünde Kasraian vd. (2020) fikirlerini doğrulamaktadır. AIRF ve URB arasındaki yayılım göstergelerinde ise seçili tüm ülkelerde kentleşmenin net iletici olduğu ve havayolu yük taşımacılığının ise net alıcı olduğu gözükmektedir. Bu bulgular eşiğinde ulaşım göstergesi olarak kullanılan havayolu ulaşımı ile kentleşmenin arasında kentleşmeden ulaşıma bir ilişki gözükmektedir.

Kentleşme dinamikleri belirlendikten sonra olası ilişkileri bu dinamiklere göre yorumlamak literatürdeki boşlukların doldurulmasına yardım edecektir. Yapısal değişikliklere verilen bölgesel tepkiler olarak belirtilen ilk dinamik ülke içerisinde olduğu kadar ülkeler arası da olabilir. Tarihsel olarak geniş bir perspektiften bakıldığında ulaşım, belirli bir grup ya da bölgeyle sınırlı kalmamış, erişilebilirlik sayesinde etkileşime girdiği diğer bölgelere yayılmıştır. Bu etkileşim, bölgesel düzeyde ülke içerisinde ve kimi zaman ülkeler arası nüfus hareketliliği faaliyetlerine neden olabilmektedir. Böylece kentleşme, ulaşım bağlamında olan bir çözülme, yoğunlaşma ve akım düzlemine tekabül etmektedir. Yukarıdaki analiz sonuçlarına göre kentleşmenin yük ve yolcu taşımacılığ 1 ile etkileşimi beklendiği gibi en yüksek oranlarda ülke içerisindedir ve diğer ülkelere de yayılım göstermektedir.

İkinci dinamik olarak doğum ve ölüm oranları gibi demografik değişkenlere bağlı olarak kent nüfusunun yüzdesel değişimi, altyap1 ve yenileme faaliyetlerine doğrudan veya dolaylı olarak etki edebilmektedir. Üçüncü dinamik olan ülkeler arası nüfus hareketliliğinin belirleyicileri eğitim, iş, yaşam tarzı, turizm, yatırım, zevk ve tercihler gibi çok geniş parametreleri kapsayabilir. Bunların dışında, başta dış ticaret yani ithalat-ihracat olmak üzere çeşitli ekonomik faaliyetler de ülkelerin davranışlarına ve yapısal değişimlerine etki edebilir. Ülkeler arasındaki etkiler düşünüldüğünde; ulaşım ağı ve altyapıları sadece ülke içi ihtiyaçları karşılamak için 
değil aynı zamanda insanları, pazarları ve kültürleri birbirine bağlayarak erişilebilirlik ihtiyaçlarını gidermek için de yapılmaktadır. Hava taşımacılığının ülkeler arası etkileşim parametreleri, ulaşım ve taşımacılık boyutundaki entegrasyonu göstermesi bakımından önemli olan bulgular arasındadır. Böylece ulaşım altyapı yatırım ve hizmetlerinin diğer ülkeler boyutunda da önemli olma durumu, politika yapılar arasındaki koordinasyona işaret etmektedir.

Bunlara ek olarak ülkelerin kullandıkları ulaşım modları bağlamındaki yöntem ve araçlar teknik olarak benzerlik göstermektedir. Özellikle uçak üreticileri düşünüldüğünde sadece birkaç uçak üreticisinin araç-tedarik noktasında ihtiyaçları karşıladığı bilinmektedir. Avrupa'da seyahat etme kısıtlamalarının dünyanın geri kalanına görece daha rahat olması insanların yaşam şekillerine de etki edebilmektedir. Bu şekliyle düşünüldügünde başta çalışma, seyahat ve eğitim olmak üzere birçok husustan ötürü nüfus hareketliliğini teşvik eden nedenler nüfusun mobilitesini sadece ülke içerisinde sınırlı olmaktan kurtarmış ve ülkeler arası boyuta taşımıştır. Yük taşımacılığı kapsamında değerlendirildiğinde ise Avrupa'da uygulanmakta olan Gümrük Birliği ticareti desteklemektedir ve ülkelerin gelişimine katkı sunmaktadır. Çalışmada elde edilen ampirik bulgular dahilinde, AIRF ve AIRP ile kentleşme arasındaki etkileşim parametreleri ülkeler arası boyutta ülke içine nazaran daha yüksek oranlarda seyretmektedir.

Nüfus ve demografik özellikleri bakımından veri mevcudiyeti kapsamında seçili ülkelerde, ülke içi ve ülkeler arası kentleşme ve ulaşım yayılım etkileri politika yapıcılara nüfus hareketliliği, demografik değişimler ve yapısal tepkiler ışı̆̆ında kentleşmenin güçlü ulaşım ağlarına ihtiyaç duyduğu mesajını vermektedir. Ulaşım ağı, çeşitleri ve altyapısı ihtiyaçları karşılamak için sürdürülebilir olmalı ve teşvik edilmelidir. Kentleşme planlanmalı ve sürdürülebilir politikalar benimsenmelidir. Ulaşım ve kentleşme değerlendirilirken coğrafik, ekolojik, kültürel ve sosyal değişkenler dikkate alınmalıdır. İlgili araştırmalar ve kapsamlar akademik çevrelerce ulaşım sistemleri, kentleşme ve ekonomik göstergeler arasında genişletilmelidir. Erişilebilirlik kapsamında güncel teknolojik çalışmalar takip edilmeli, araştırma ve geliştirme faaliyetlerine hız verilmelidir. Son olarak, ampirik bulgular ışında, ülkeler arası ulaşım politikalarının kentleşme ekseninde entegre edilmesi hedeflenmelidir.

\section{KAYNAKÇA}

Amin, A., Altinoz, B., \& Dogan, E. (2020). Analyzing the determinants of carbon emissions from transportation in European countries: the role of renewable energy and urbanization. Clean Technologies and Environmental Policy, 22(8), 1725-1734.

Antonakakis, N., Chatziantoniou, I., \& Gabauer, D. (2020). Refined Measures of Dynamic Connectedness based on Time-Varying Parameter Vector Autoregressions. Journal of Risk and Financial Management, 13(4), 84. 
Antrop, M. (2004). Landscape change and the urbanization process in Europe. Landscape and urban planning, 67(1-4), 9-26.

Arvin, M. B., Pradhan, R. P., \& Norman, N. R. (2015). Transportation intensity, urbanization, economic growth, and $\mathrm{CO} 2$ emissions in the G-20 countries. Utilities Policy, 35, 50-66.

Daniere, A. G. (1999). Sustainable Urbanization in Megacities: Role of nonmotorized transportation. Transportation research record, 1695(1), 26-32.

Diebold, F. X., \& Yilmaz, K. (2012). Better to give than to receive: Predictive directional measurement of volatility spillovers. International Journal of Forecasting, 28(1), 57-66.

Diebold, F. X., \& Yilmaz, K. (2014). On the network topology of variance decompositions: Measuring the connectedness of financial firms. Journal of Econometrics, 182(1), 119-134.

Goetz, A. R. (1992). Air passenger transportation and growth in the US urban system, 1950-1987. Growth and change, 23(2), 217-238.

Kasraian, D., Raghav, S., \& Miller, E. J. (2020). A multi-decade longitudinal analysis of transportation and land use co-evolution in the Greater Toronto-Hamilton Area. Journal of Transport Geography, 84, 102696.

Kojima, R. (1996). Introduction: population migration and urbanization in developing countries. The Developing Economies, 34(4), 349-369.

Kotavaara, O., Antikainen, H., \& Rusanen, J. (2011). Urbanization and transportation in Finland, 1880-1970. Journal of Interdisciplinary History, 42(1), 89-109.

Krugman, P. (1991). Increasing returns and economic geography. Journal of political economy, 99(3), 483-499.

Liu, T. Y., \& Su, C. W. (2021). Is transportation improving urbanization in China? Socio-Economic Planning Sciences, 101034.

Maparu, T. S., \& Mazumder, T. N. (2017). Transport infrastructure, economic development and urbanization in India (1990-2011): Is there any causal relationship? Transportation research part A: policy and practice, 100, 319-336.

Motamed, M. J., Florax, R. J., \& Masters, W. A. (2014). Agriculture, transportation and the timing of urbanization: Global analysis at the grid cell level. Journal of Economic Growth, 19(3), 339-368.

Njoh, A. J. (2003). Urbanization and development in sub-Saharan Africa. Cities, 20(3), 167-174.

Shahbaz, M., Chaudhary, A. R., \& Ozturk, I. (2017). Does urbanization cause increasing energy demand in Pakistan? Empirical evidence from STIRPAT model. Energy, 122, 83-93.

Sharma, P. (2003). Urbanization and development. Population monograph of Nepal, 1, 375-412.

The World Bank, DataBank, World Development Indicators https://databank.worldbank.org/source/world-development-indicators, accessed in 2021. 
Dündar, T., Beyzatlar, M. A. DEÜ SBE Dergisi, Cilt: 23, Özel Sayl

Wang, Y., Liu, Z., He, C., Xia, P., Liu, Z., \& Liu, H. (2020). Quantifying urbanization levels on the Tibetan Plateau with high-resolution nighttime light data. Geography and Sustainability, 1(3), 233-244.

Zenou, Y. (2011). Search, migration, and urban land use: The case of transportation policies. Journal of Development Economics, 96(2), 174-187. 